\title{
BERMAIN DRAMA MELALUI PEMBELAJARAN ROTATING ROLES
}

\author{
Mustakim Sagita1, Muhammad Iqbal2 \\ 1,2Program Studi Pendidikan Bahasa Inggris \\ FKIP Universitas Jabal Ghafur, Aceh \\ e-mail : aqimbate@gmail.com, iqbalunigha31@gmail.com
}

\begin{abstract}
Drama is a form of literary work that has a part to be played by an actor, containing imitations of portraits of human life projected into a show. Playing drama is an activity to portray the characters in the story. In playing a drama, a player must be able to imagine the setting and actions of the actor and can use the voice in accordance with understanding of the feelings and thoughts of the actor. rotating roles is an active learning technique that provides opportunities for students to learn by practicing skills through characterization of characters or plays about certain situations in real life.This research is a classroom action research conducted in two cycles. Each cycle consists of four stages, namely: (1) planning, (2) implementation, (3) observation, and (4) reflection. This research was carried out collaboratively between researchers and English teachers. The subject of this study was high school level students in Pidie district and the object of this research was the students' playing skills using the rotating roles technique. Data collection is obtained through observation, field notes, practice tests playing drama, and interviews. The instruments used are field notes, observation sheets, questionnaires, and assessment sheets. Data analysis was carried out with qualitative descriptive techniques supported by quantitative data. The validity of the data is obtained through validity, namely democratic validity, results validity, process validity and dialogic validity, to achieve data reliability by presenting original data from the research results, such as field notes and interview transcripts.
\end{abstract}

Keywords: Drama, rotating roles, speaking ability.

\begin{abstract}
ABSTRAK
Drama adalah salah satu bentuk karya sastra yang memiliki bagian untuk diperankan oleh seorang aktor, berisi tiruan-tiruan potret kehidupan manusia yang diproyeksikan ke dalam suatu pertunjukan. Bermain drama merupakan kegiatan memerankan tokoh yang ada dalam cerita. Dalam memerankan drama seorang pemain harus dapat membayangkan latar dan tindakan pelaku dan dapat menggunakan suara sesuai dengan pemahamannya terhadap perasaan dan pikiran pelaku. rotating roles adalah suatu teknik pembelajaran aktif yang memberikan kesempatan kepada peserta didik untuk belajar dengan cara mempraktikan keterampilan melalui pemeranan tokoh atau lakon tentang situasi tertentu dalam kehidupan nyata.

Penelitian ini merupakan penelitian tindakan kelas yang dilaksanakan sebanyak dua siklus. Setiap siklus terdiri dari empat tahap yaitu: (1) perencanaan, (2) pelaksanaan, (3) pengamatan, dan (4) refleksi. Penelitian ini dilaksanakan secara kolaboratif antara peneliti bersama guru Bahasa Inggris. Subjek penelitian ini adalah siswa tingkat sekolah menengah atas di kabupaten Pidie dan objek penelitian ini adalah keterampilan bermain drama Siswa dengan menggunakan teknik rotating roles. Pengumpulan data diperoleh melalui observasi, catatan lapangan, tes praktik bermain drama, dan wawancara. Adapun instrumen yang digunakan catatan lapangan, lembar pengamatan, angket, dan lembar penilaian. Analisis data dilakukan dengan teknik deskriptif kualitatif yang didukung oleh data kuantitatif. Keabsahan data diperoleh melalui validitas, yakni validitas demokratis, validitas hasil, validitas proses dan validitas dialogis,
\end{abstract}


untuk mencapai reliabilitas data dilakukan dengan cara menyajikan data asli hasil penelitian, seperti catatan lapangan dan transkrip wawancara.

Kata kunci : Drama, rotating roles, kemampuan berbicara

\section{Pendahuluan}

Pendidikan merupakan pilar utama dalam pembentukan mental atau karakter seseorang. Hal ini dikarenakan pendidikan sudah dimulai semenjak seseorang dilahirkan. Pendidikan adalah proses sepanjang hayat dan perwujudan pembentukan diri secara utuh dalam arti pengembangan segenap potensi diri dalam rangka pemenuhan semua komitmen manusia sebagai makhluk individu, sebagai makhluk sosial dan makhluk Tuhan (Sumitro,2006:19).

Sesuai dengan standar isi kurikulum, pembelajaran bahasa dan sastra secara umum meliputi empat keterampilan berbahasa. Pembelajaran tersebut meliputi kegiatan atau kemampuan menyimak atau mendengarkan (Listening), berbicara (Speaking), membaca (Reading), dan menulis (Writing). Apabila pembelajaran dilakukan dengan mengaitkan keempat kegiatan tersebut maka kegiatan pembelajaran akan lebih terfokus. Misalnya dalam kegiatan pembelajaran sastra, apabila pembelajarannya dilakukan dengan mengaitkan keempat keterampilan berbahasa tersebut maka secara bertahap Siswa akan memiliki kemampuan untuk mengapresiasi karya sastra.

Berbicara merupakan proses komunikasi secara lisan. Hal itu sejalan dengan pendapat yang dikemukakan Haryadi (1997: 54), bahwa berbicara adalah suatu penyampaian maksud (ide, pikiran, isi hati) seseorang kepada orang lain dengan menggunakan bahasa lisan, sehingga maksud tersebut dapat dipahami orang lain. Berbicara sebagai salah satu proses penyampaian maksud kepada orang lain secara lisan, keberhasilannya ditentukan oleh kemampuan pembicara. Kemampuan tersebut salah satunya bisa berbentuk terhadap makna pesan yang hendak disampaikan. Proses pencapaian keterampilan berbicara Siswa perlu mendapatkan bimbingan dari guru melalui berbagai latihan pengembangan kemampuan kognitif, afektif, dan psikomotor.

Berbicara merupakan proses komunikasi secara lisan. Hal itu sejalan dengan pendapat yang dikemukakan Haryadi (1997:54), bahwa berbicara adalah suatu penyampaian maksud (ide, pikiran, isi hati) seseorang kepada orang lain dengan menggunakan bahasa lisan, sehingga maksud tersebut dapat dipahami orang lain. Berbicara sebagai salah satu proses penyampaian maksud kepada orang lain secara lisan, keberhasilannya ditentukan oleh kemampuan pembicara.

Proses pencapaian keterampilan berbicara Siswa perlu mendapatkan bimbingan dari guru melalui berbagai latihan. Salah satu latihan pengembangan keterampilan berbicara di sekolah adalah dengan pembelajaran bermain drama, yang termasuk ke dalam pembelajaran sastra.

Bermain drama merupakan kegiatan memerankan tokoh yang ada dalam cerita. Dalam memerankan drama seorang pemain harus dapat membayangkan latar dan tindakan pelaku dan dapat menggunakan suara sesuai dengan pemahamannya terhadap perasaan dan pikiran pelaku.

\section{Metode Drama Hakikat Drama}

Drama berasal dari bahasa Yunani “ Draomai" yang berarti berbuat, berlaku, bertindak, atau beraksi. Drama berarti perbuatan, tindakan, beraksi, atau action (Waluyo, 2010:2). Menurut Ferdinant Brunetierre, drama haruslah melahirkan kehendak manusia dengan action. Menurut Belthazar Vertagen, drama adalah kesenian melukiskan sifat dan sikap manusia dengan gerak (Harymawan, 1993:1-2). Drama merupakan tiruan kehidupan manusia yang diproyeksikan di atas pentas (Waluyo, 2010: 
1). Dari beberapa pendapat tersebut dapat disimpulkan bahwa drama adalah sebuah rangkaian cerita yang berisi konflik manusia, berbentuk dialog, yang diekspresikan melalui pentas pertunjukan dengan menggunakan percakapan dan action dihadapan para penonton.

Dalam kaitannya dengan pendidikan watak, drama juga dapat membantu mengembangkan nilai-nilai yang ada dalam diri peserta didik, memeperkenalkan kehidupan manusia dari kebahagiaan, keberhasilan, kepuasan, kegembiraan, cinta, kesakitan, keputusasaan, acuh tak acuh, benci dan kematian. Drama juga dapat memberikan sumbangan pada pengembangan kepribadian yang kompleks, misalnya ketegaran hati, imajinasi, dan kreativitas. Hal ini sejalan dengan apa yang dikemukakan oleh Endraswara (2005:192).

\section{Pembelajaran Drama}

Pembelajaran drama di sekolah dapat dibagi menjadi dua golongan, yaitu: 1) pembelajaran teks drama yang termasuk sastra, dan 2) pementasan drama yang termasuk bidang teater (Waluyo, 2010:162). Dalam pembelajaran teks drama yang termasuk sastra, pementasan drama dilakukan di kelas oleh guru Bahasa Inggris. Disarankan agar dilakukan pementasan, meskipun hanya sekali dalam satu semester dan berupa pementasan sederhana. Hal ini dimaksudkan untuk melatih keterampilan Siswa mulai dari pementasan kecil, sebelum akhirnya menyajikan pementasan yang lebih besar (teater sekolah).

Dalam pembelajaran drama, Siswa tidak cukup jika hanya diberi pengetahuan tentang drama, tetapi mereka harus mampu untuk mengapresiasi (unsur yang termasuk afektif), dan mementaskan (psikomotor) (Waluyo, 2010:167). Jadi dalam pembelajaran, aspek kognitif, afektif dan psikomotorik dapat diperoleh secara merata oleh Siswa. Dalam setiap pengajaran, termasuk pengajaran drama, tujuan harus dapat diketahui secara jelas. Hal ini agar proses pembelajaran lebih terfokus, sehingga apa yang menjadi tujuan dari pembelajaran tersebut dapat tercapai.

Berbicara mengenai tujuan pengajaran, kita tidak akan lepas dari tokoh populer, yaitu Benjamin S Bloom. Waluyo (2010:167) mengatakan bahwa untuk merumuskan lebih jelas mengenai tujuan pembelajaran sesuai dengan teori Bloom, maka perlu diketahui penjelasan rinci kawasan-kawasan tujuan mengajar beserta contoh nyata kerja operasional yang berguna untuk menyusun tujuan instruksional khusus. Ketiga domain tujuan mengajar menurut Benjamin S Bloom melalui Waluyo (2010: 167-169) adalah sebagai berikut.

a. Kognitif

Kawasan kognitif dalam tujuan pengajaran berisi perilaku-perilaku yang lebih menekankan pada aspek intelektual. b. Afektif

Kawasan afektif dalam tujuan pengajaran berisi perilaku-perilaku yang lebih menekankan pada aspek perasaan dan emosi.

\section{c. Psikomotorik}

Kawasan Psikomotorik berisi aspekaspek yang lebih menekankan pada keterampilan motorik. Dalam drama, jelas bahwa tujuan pengajaran tidak hanya terhenti pada kognitif dan afektif, tapi juga psikomotor (praktik bermain drama). Dalam bermain drama, pementasan dapat berjalan dengan baik jika aktor atau aktris dibekali pengetahuan dan sikap. Jadi permainannya bukan sekedar gerak motorik belaka.

Dalam pembelajaran drama, pementasan drama memasuki kawasan psikomotorik, akan tetapi dijiwai oleh aspek kognitif dan afektif. Ketiga hal tersebut menyatu dalam diri aktor yang bermain drama. Keseimbangan antara aspek kognitif, afektif dan psikomotorik akan melahirkan suatu acting yang baik.

\section{Keterampilan Bermain Drama}

Drama naskah belum lengkap jika belum diperankan atau dipentaskan. Berperan adalah menjadi orang lain sesuai 
dengan tuntutan lakon drama (Waluyo,2010:114). Sejauh mana keterampilan seorang aktor dalam berperan, baru dapat dilihat setelah ia memerankan dan mengekspresikan tokoh yang dibawakannya.

Keterampilan bermain drama adalah keterampilan seseorang dalam memerankan suatu peran atau karakter tokoh yang ada di dalam drama. Kemampuan memerankan karakter tokoh dalam bermain drama tidak terlepas dari dialog dan gerakan, karena inti dari sebuah drama adalah pada kedua aspek tersebut.

a. Mimik.

Mimik adalah pernyataan atau perubahan muka: mata, mulut, bibir, hidung, kening. Mimik juga dapat diartikan sebagai ekspresi wajah. Tanpa mimik atau ekspresi, permainan drama akan terasa kurang lengkap. Hal ini sejalan dengan apa yang dikemukakan oleh Hamzah melalui Harymawan (1993:46), Ia mengatakan meskipun bermacam-macam gerakan sudah bagus, suara telah jadi jaminan, dan diksi juga mengena, tetapi ekspresi mata kosong saja, maka dialog yang diucapkan kurang meyakinkan penonton, karena itu, permainannya menjadi hambar atau datar saja.

b. Gestur

Gestur atau plastik merupakan cara bersikap dan gerakan-gerakan anggota badan. Gestur juga dapat diartikan sebagai sikap. Gestur atau plastik juga dapat diartikan sebagai gerakan tubuh. Harymawan (1993:46) menyatakan bahwa sikap dan gerak dengan sendirinya akan terpengaruh oleh mimik dan pada umumnya bergantung juga pada tanda yang sama, tak setegas dan seprinsipil mimik.

c. Diksi

Diksi merupakan cara penggunaan suara atau ucapan. Diksi memberikan kebebasan pada aktor untuk menghidupkan individualitasnya dalam peranan, karena diksi tidak ditentukan oleh pengarang naskah drama. Diksi ditentukan oleh aktor itu sendiri. Oleh karena itu, diksi dapat mempengaruhi arti dari suatu kalimat (Harymawan, 1993: 48).

\section{Strategi Pembelajaran Aktif (Active Learning)}

Dalam kegiatan pembelajaran, guru harus memiliki strategi agar anak didik dapat belajar secara efektif. R. David melalui Wina Sanjaya (2008) menyebutkan bahwa dalam strategi pembelajaran terkandung makna perencanaan. Artinya, bahwa strategi pembelajaran dapa dasarnya masih bersifat konseptual. Salah satu langkah untuk memiliki strategi itu adalah harus menguasai teknik penyajian atau biasa disebut metode. Djamarah (2010: 46) menyatakan bahwa metode adalah suatu cara yang dipergunakan untuk mencapai tujuan yang telah ditetapkan. Pemilihan metode pembelajaran yang tepat akan membantu kegiatan belajar mengajar, sehingga apa yang menjadi tujuan pembelajaran akan tercapai (Pringgo Widagda, 2002:56).

Pembelajaran aktif (active learning) merupakan suatu strategi pembelajaran yang bertujuan untuk mengaktifkan Siswa dalam kegiatan pembelajaran. Pada pembelajaran aktif (active learning) Siswa dikondisikan dalam sikap mecari (aktif) bukan sekedar menerima (reaktif) (Melvin Silberman, 2011: 116). Dengan kata lain, mereka mencari jawaban atas pertanyaan-pertanyaan yang diajukan kepada mereka. Mereka mengupayakan sendiri pemecahan atas permasalahan yang diajukan oleh guru.

1) Formasi regu tembak

Teknik ini merupakan format yang cepat dan dinamis yang bisa digunakan untuk berbagai macam tujuan, misalnya menguji dan memerankan suatu lakon. Teknik ini menampilkan pasangan secara bergilir. Siswa mendapat peluang untuk merespon dengan cepat terhadap pertanyaanpertanyaan yang diajukan secara bertubi-tubi dan jenis tantangan lain.

2) Pemeranan lakon yang tidak membuat grogi

Teknik ini mengurangi ancaman atau rasa khawatir Siswa dalam pemeranan lakon. 
Caranya adalah dengan menempatkan guru pada peran utama dan melibatkan Siswa dalam memberikan respons dan menetapkan arah skenarionya.

3) Pemeranan lakon oleh tiga orang Siswa

Teknik ini memperluas pemeranan lakon tradisional dengan menggunakan tiga Siswa yang berbeda dalam situasi pemeranan lakon yang sama. Teknik ini juga menunjukkan pengaruh dan variasi gaya individual terhadap akibat dari situasi itu.

4) Rotating roles (pemeranan bergilir)

Teknik ini merupakan cara yang bagus untuk memberi kesempatan pada tiap Siswa untuk mempraktikkan keterampilan melalui pemeranan lakon tentang situasi di kehidupan nyata.

5) Pemeragaan cara

Teknik ini memberi kesempatan pada Siswa untuk mempraktikan, melalui peragaan, keterampilan khusus yang diajarkan di kelas. Siswa diberi banyak waktu untuk membuat skenario mereka sendiri dan menentukan bagaimana mereka ingin mengilustrasikan keterampilan dan teknik yang baru saja dibahas di kelas.

\section{Teknik Pembelajaran Rotating Roles}

Belajar aktif adalah suatu istilah yang digunakan dalam prosedur pembelajaran interaktif, dimana Siswa belajar bersamasama dalam kelompok-kelompok kecil untuk memecahkan berbagai masalah. (M. Silberman, 2011: 62). Setiap Siswa tidak hanya menyelesaikan tugas individualnya, tetapi juga berkewajiban membantu tugas sekelompoknya, sampai semua anggota kelompok memahami suatu konsep (Kagan, 2000:1)

Teknik pembelajaran rotating roles adalah salah satu bagian dari strategi pembelajaran active learning. Strategi pembelajaran active learning adalah suatu strategi pembelajaran yang bertujuan untuk mengaktifkan Siswa dalam kegiatan pembelajaran (M. Silberman, 2011: 30). Dalam hal ini, guru dapat menempatkan
Siswa dalam kelompok dan memberi mereka tugas yang menuntut mereka untuk bergantung satu sama lain dalam mengerjakannya, sehingga Siswa lebih terlibat dalam kegiatan belajar (Melvin L. Silberman, 2011: 30).

Teknik rotating roles atau permainan bergilir merupakan suatu teknik pembelajaran yang dalam penerapannya dilakukan dengan cara memberikan kesempatan pada setiap peserta didik untuk melatih kecakapan melalui bermian peran tentang situasi kehidupan nyata (Melvin L. Silberman, 2011: 232).

Teknik pembelajaran ini dinamakan rotating roles atau permainan bergilir karena dalam penerapannya, Siswa diberi kesempatan secara bergilir dalam mempresentasikan hasil belajarnya. Melvin L Silberman (2011: 232-233) mengemukakan bahwa prosedur atau tahapan dalam teknik pembelajaran rotating roles adalah sebagai berikut.

a) Siswa dibagi menjadi kelompokkelompok yang beranggotakan tiga orang (jumlah anggota kelompok dapat divariasi menyesuaikan jumlah Siswa)

b) Setiap kelompok membuat skenario kehidupan nyata yang membahas topik yang telah ditentukan.

c) Setelah masing-masing kelompok menulis skenarionya pada lembar yang terpisah, satu anggota dari tiap kelompok menyampaikan skenario itu pada kelompok lain dan ia ada ketika anggota kelompok lain membaca skenario untuk mengklarifikasi atau memberi informasi tambahan jika perlu. Siswa kemudian kembali ke kelompok aslinya.

d) Setiap ronde seharusnya terdiri paling tidak 10 menit bermain peran dengan 5 sampai 10 menit feedback dari pengamat. 
e) Dalam setiap ronde, pengamat seharusnya berkonsentrasi pada identifikasi apakah yang dilakukan sudah berjalan dengan baik.

f) Setelah semua tampil, kumpulkan kembali semua kelompok untuk diskusi umum.

Prosedur di atas dapat dimodifikasi sesuai dengan keadaan kelas, keadaan Siswa atau jenis pembelajaran yang dilakukan.

\section{Pembelajaran Bermain Drama melalui} Teknik Pembelajaran Rotating Roles.

Teknik rotating roles termasuk dalam pengembangan keterampilan bermain peran Siswa. Teknik ini bisa digunakan untuk menggairahkan diskusi, menyemarakkan suasana, dan mempraktikan keterampilan dalam pembelajaran seni peran ( $\mathrm{M}$. Silberman 2011: 55). Melalui teknik ini, Siswa diajak untuk aktif dan dituntut untuk menuangkan ide secara cepat dan bergiliran. Penerapan teknik rotating roles ini diharapkan akan dapat membantu meningkatkan keterampilan bermain drama siswa tingkat sekolah menengah atas di kabupaten Pidie.

Teknik rotating roles yang digunakan dalam penelitian ini telah dimodifikasi menyesuaikan dengan kondisi Siswa .

\section{Kerangka Pikir}

Dalam pembelajaran Bahasa Inggris, keterampilan bermain drama harus diajarkan secara sungguh-sungguh. Terutama bagi Siswa tingkat SMA. Hal itu mengingat pentingnya manfaat dari keterampilan bermain drama itu sendiri, terutama dalam bidang pembelajaran drama. Pada kenyataannya, pembelajaran bermain drama masih dianggap kegiatan yang menakutkan, Siswa menjadi kurang aktif dalam pembelajaran, kurang antusias, dan tidak berani untuk berpendapat.
Penggunaan teknik rotating roles diharapkan dapat menjadi salah satu teknik pembelajaran yang efektif sehingga Siswa menjadi terpacu untuk bermain drama dengan baik.

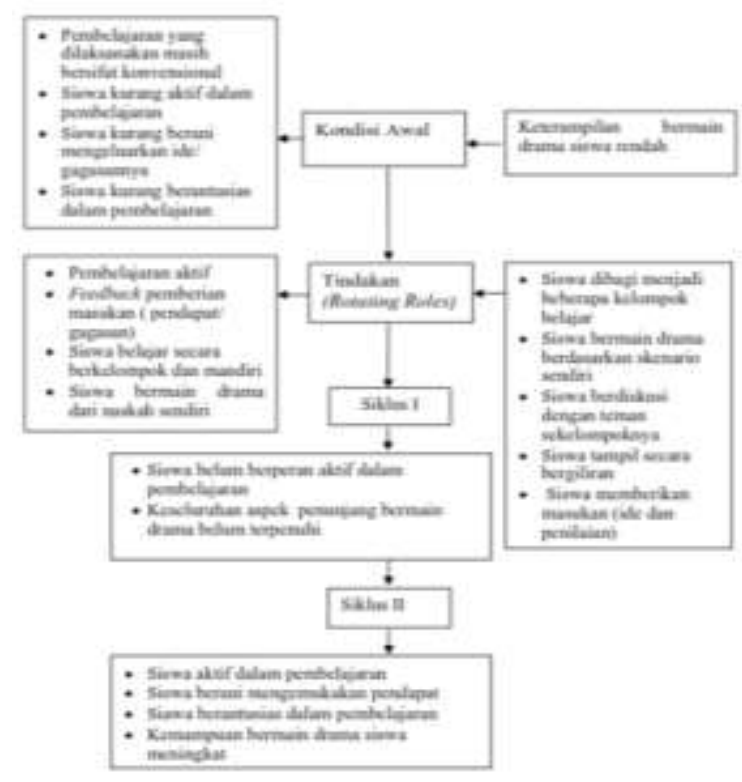

Gambar 1. Kerangka Pikir

\section{Hasil dan Pembahasan \\ Pendekatan Penelitian}

Penelitian ini merupakan penelitian tindakan kelas (PTK). Penelitian tindakan kelas (PTK) merupakan penelitian yang dilakukan oleh guru di kelasnya sendiri dengan cara (1) merencanakan, (2) melaksanakan, dan (3) merefleksikan tindakan secara kolaboratif dan partisipatif dengan tujuan memperbaiki kinerjanya sebagai guru, sehingga hasil belajar Siswa dapat meningkat (Kusumah, 2010: 9). Secara singkat, PTK merupakan bentuk kajian yang sistematis reflektif yang dilakukan dengan cara atau metodologi tertentu oleh pelaku tindakan (guru) demi kepentingan peserta didik dalam memperoleh hasil belajar yang memuaskan.

Acuan yang dijadikan pedoman penelitian ini adalah model penelitian tindakan kelas model Kemmis dan Mc. Taggart yang mencakup perencanaan tindakan, implementasi tindakan dan observasi, serta refleksi. Gambar model 
penelitian tindakan kelas dapat dilihat sebagai berikut.

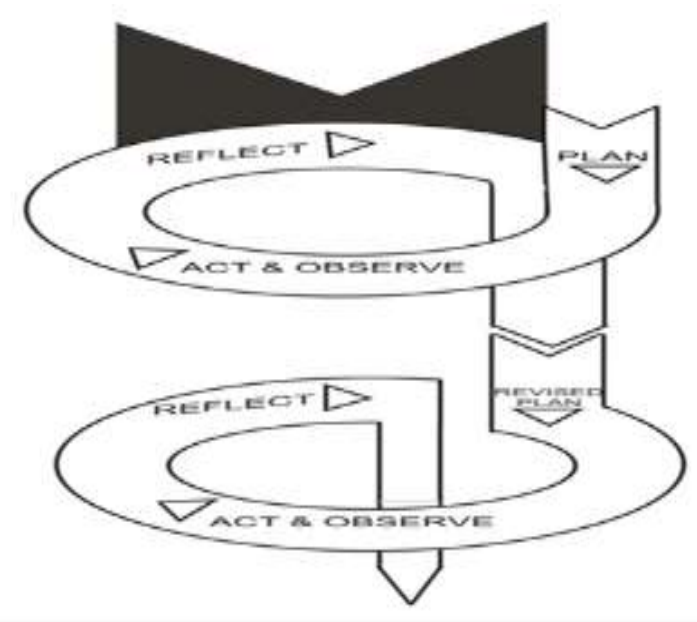

Gambar 2 . Model Penelitian Tindakan Kelas

Kemmis dan Mc. Taggart melalui Arikunto (2009:16)

Dari gambar siklus tersebut, maka tahap-tahap dalam penelitian tindakan meliputi: (1) Plan (perencanaan); (2) Act (pelaksanaan tindakan), (3) Observe (pengamatan); dan (4) Reflect (refleksi).

\section{Setting Penelitian}

Setting penelitian adalah lokasi atau tempat penelitian dilakukan di kelas Drama siswa tingkat sekolah menengah atas di kabupaten Pidie.

\section{Subjek dan Objek Penelitian}

Subjek penelitian ini adalah siswa tingkat sekolah menengah atas di kabupaten Pidie untuk pembelajaran Drama, sedangkan objek penelitian ini adalah keterampilan bermain drama siswa tingkat sekolah menengah atas di kabupaten Pidie, yang mencakup proses dan hasil.

\section{Rancangan Penelitian}

Penelitian berawal dari adanya masalah dalam pembelajaran bermain drama di siswa tingkat sekolah menengah atas di kabupaten Pidie. Masalah yang ada diamati dan dieksplorasi, yang kemudian menjadi dasar perencanaan penelitian. Perencanaan dilakukan secara umum dan khusus. Perencanaan umum meliputi keseluruhan penelitian, sedangkan perencanaan khusus mencakup tiap siklus penelitian yang selalu dilakukan di awal siklus. Selanjutnya dilakukan pemberian tindakan (acting) dan pengamatan (observing) selama tindakan diberikan. Akhir siklus dilakukan refleksi untuk melihat ketercapaian hasil tindakan yang telah diberikan.

Tindakan yang dilakukan adalah penerapan teknik pembelajaran rotating roles dalam meningkatkan keterampilan bermain drama pada siswa tingkat sekolah menengah atas di kabupaten Pidie. Pada siklus pertama Siswa akan mendapatkan praktik bermain drama dengan teknik rotating roles. Setelah itu, hasil refleksi dari siklus pertama akan dijadikan sebagai dasar untuk menentukan tindakan berikutnya.

\section{Teknik Analisis Data}

Penelitian ini menggunakan teknik analisis data deskriptif kualitatif yang didukung oleh data kuantitatif, yaitu mendeskripsikan kemampuan bermain drama sebelum dan sesudah implementasi tindakan. Analisis kualitatif digunakan untuk data kualitatif yang berupa hasil wawancara, tes bermain drama, angket, lembar observasi, dan catatan lapangan. Data kuantitatif diperoleh dari hasil penilaian bermain drama sebelum dan sesudah diberi tindakan.

Pada penelitian ini, pembahasan difokuskan pada (1) deskripsi awal ,(2) proses pelaksanaan penelitian tindakan kelas dengan teknik pembelajaran rotating roles dan (3) peningkatan keterampilan bermain drama melalui teknik pembelajaran rotating roles.

\section{Pelaksanaan Penelitian Tindakan Kelas Melalui Teknik Pembelajaran Rotating Roles}

Pembelajaran keterampilan bermain drama melalui teknik pembelajaran rotating roles dilakukan selama 2 siklus. Siklus 
pertama dan kedua dilaksanakan sesuai dengan rencana. Siklus II merupakan perbaikan siklus I yang bertujuan untuk memaksimalkan aspek-aspek yang masih rendah.

Alat ukur yang digunakan untuk mengetahui peningkatan keterampilan bermain drama siswa sebelum maupun sesudah implementasi tindakan adalah tes praktik bermain drama. Penilaian praktik tersebut mencakup lima aspek yaitu: ekspresi; (2) penghayatan; (3) gerak; (4) intonasi; dan (5) artikulasi.

Proses pembelajaran melalui teknik pembelajaran rotating roles dilakukan secara bertahap. Pada awal pertemuan guru menjelaskan prosedur kegiatan pembelajaran bermain drama melalui teknik pembelajaran rotating roles, membagikan naskah drama dan membagi kelas dalam beberapa kelompok sesuai naskah. Kemudian guru meminta salah satu siswa dari masing-masing kelompok untuk menyampaikan skenario yang akan dimainkan pada kelompok yang lain dan kelompok lain boleh memberikan koreksi. Setelah siswa membaca dan memahami naskah, guru meminta tiap kelompok untuk melakukan permainan drama di depan secara bergilir, kelompok lain memperhatikan dan memberikan masukan atau penilaiannya setelah permainan selesai, begitu seterusnya sampai semua kelompok mendapat giliran untuk bermain drama. Di akhir pembelajaran, kelas dikondisikan seperti semula dan dilakukan diskusi kelas tentang pembelajaran yang baru saja dilaksanakan.

\section{Peningkatan Keterampilan Bermain Drama Melalui Teknik Pembelajaran Rotating Roles}

Penilaian keterampilan siswa dilakukan dengan cara mengamati aspekaspek yang telah ditentukan. Penilaian dilakukan untuk mengukur keterampilan siswa dalam bermain drama sebelum dan sesudah pelaksanaan tindakan. Berdasarkan pengamatan, hasil penelitian menunjukkan adanya peningkatan kemampuan bermain drama siswa pada aspek kebahasaan maupun nonkebahasaan. Hal tersebut diketahui dari perubahan yang ke arah yang lebih baik dan juga peningkatan skor pada aspek kebahasaan yang meliputi intonasi dan artikulasi, dan juga aspek nonkebahasaan meliputi ekspresi, penghayatan dan gerak. Berdasarkan hasil tes awal pada pratindakan, skor ratarata tiap aspek sebelum implementasi tindakan masih tergolong rendah, beberapa aspek tersebut antara lain: ekspresi $(4,59)$; penghayatan $(4,86)$; gerak $(4,66)$; intonasi $(5,09)$; dan artikulasi $(5,53)$. Nilai rata-rata sebelum implementasi tindakan adalah 4,95. Rendahnya skor beberapa aspek sebelum implementasi tindakan disebabkan oleh beberapa faktor, antara lain: masih ada beberapa siswa yang kurang serius dalam berlatih dengan teman sekelompoknya, siswa kurang percaya diri dan malu- malu dalam bermain drama, sehingga acting yang dihasilkan tidak maksimal.

Untuk meningkatkan kemampuan masing-masing aspek, peneliti dan kolaborator melakukan pemberian tindakan tahap pertama pada siklus I. Nilai rata-rata tindaka siklus I yang dihasilkan siswa adalah 63,5.

Mengingat hasil penelitian pada tindakan siklus I belum sesuai dengan harapan peneliti, maka perlu diadakan tindakan siklus II. Siklus II dilaksanakan berdasarkan hasil refleksi pada siklus I, yakni akan lebih memfokuskan pada beberapa aspek yang masih rendah (ekspresi dan penghayatan) serta mengubah cara pemberian feedback atau masukan agar semua siswa lebih aktif dan berani selama proses pembelajaran.

Tindakan pada siklus II bertujuan untuk mengoptimalkan hasil dari siklus I. Pada tindakan siklus II ini semua siswa mencapai hasil yang lebih baik dibandingkan pada siklus sebelumnya. Jika didasarkan pada tiap-tiap indikator penilaian, nilai rata-rata dalam bermain 
drama telah menunjukkan hasil yang memuaskan, yakni sebesar 78,14. Berikut hasil penelitian pada pratindakan, siklus I dan siklus II.

Tabel 2: Perbandingan Skor Rata-rata Keseluruhan Aspek pada Pratindakan, Siklus I, dan Siklus II

\begin{tabular}{|c|c|c|c|c|}
\hline \multirow[t]{2}{*}{ No } & \multirow{2}{*}{$\begin{array}{l}\text { Aspek Penilaian } \\
\text { Bermain Drama }\end{array}$} & $\begin{array}{c}\text { Pratindak } \\
\text { an }\end{array}$ & Siklus I & Siklus II \\
\hline & & Skor & Skor & Skor \\
\hline 1. & Ekspresi & 4,59 & 6,14 & 7,71 \\
\hline 2. & Penghayatan & 4,86 & 5,92 & 7,46 \\
\hline 3. & Gerak & 4,66 & 6,34 & 8,01 \\
\hline 4. & Intonasi & 5,09 & 6,58 & 7,95 \\
\hline 5 . & Artikulasi & 5,53 & 6,77 & 7,87 \\
\hline & Jumlah & 24,73 & 31,75 & 39,03 \\
\hline & Nilai rata-rata & 49,46 & 63,5 & 78,14 \\
\hline
\end{tabular}

keterangan:

- Jumlah skor maksimal $=50$

Keberhasilan produk dapat dilihat dari peningkatan skor rata-rata pada tiap siklus. Skor rata-rata tiap aspek penilaian bermain drama setelah implementasi tindakan menjadi berpredikat baik (B). Beberapa aspek yang menunjukkan peningkatan paling signifikan adalah aspek ekspresi, gerak, dan intonasi.

Karakteristik pembelajaran melalui teknik rotating roles yang memberikan kesempatan siswa untuk belajar dengan cara mempraktikan keterampilan melalui pemeranan tokoh membuat siswa lebih terbiasa untuk berbicara di muka umum. Berbicara di hadapan banyak orang dapat memotivasi siswa agar lebih percaya diri. Adanya tuntutan untuk saling memberikan masukan (feedback) pada saat pembelajaran juga dapat melatih siswa untuk berani mengemukakan pendapat. Keberanian dan percayaan diri yang terbentuk menjadikan siswa lebih berantusias dalam melakukan praktik

Berdasarkan hasil pengisian angket pascatindakan, dapat disimpulkan bahwa penerapan teknik pembelajaran rotating roles dapat diterima oleh siswa serta memberikan motivasi dan pemahaman bagi siswa dalam bermain drama. Hal ini dapat dilihat dari hasil pengisian angket pascatindakan yang dideskripsikan dalam gambar berikut

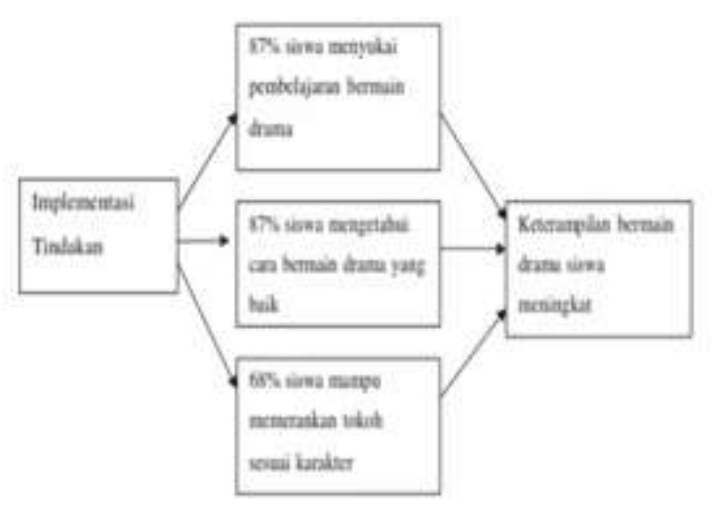

Gambar 3: Deskrispsi Keadaan Siswa

Terkait Pembelajaran Bermain Drama (pascatindakan)

Berdasarkan gambar di atas, dapat diketahui perubahan dalam diri siswa setelah adanya implementasi tindakan. Pada butir nomor 3, sebanyak $87 \%$ siswa menyatakan menyukai pembelajaran bermain drama, ini berbeda dengan sebelum adanya implementasi tindakan yang hanya $40 \%$. Penggunaan teknik pembelajaran rotating roles juga dapat meningkatkan pemahaman siswa mengenai cara bermain drama yang baik dan sesuai dengan karakter tokoh yang seharusnya. Hal ini terdapat pada butir nomor 6, yakni sebanyak $68 \%$ siswa menyatakan telah mampu memerankan tokoh dalam naskah dengan lebih mudah. Selain itu, berdasarkan hasil wawancara dengan beberapa siswa, diperoleh informasi bahwa penggunaan teknik rotating roles membuat mereka lebih mudah untuk bermain drama dan menambah semangat. Adanya koreksi membuat siswa berantusias untuk bermain drama dengan baik. Pembelajaran dengan rotating roles juga membuat siswa berani untuk bertanya dan berpendapat, sehingga terjadi interaksi yang aktif selama pembelajaran.

Dilihat dari proses dan hasil 
pembelajaran, dapat disimpulkan bahwa penerapan teknik pembelajaran rotating roles dapat meningkatkan keterampilan siswa dalam bermain drama.

\section{Kesimpulan}

Berdasarkan hasil penelitian dan pembahasan yang telah dikemukakan sebelumnya, dapat ditarik kesimpulan bahwa penggunaan teknik pembelajaran rotating roles dapat meningkatkan keterampilan bermain drama bagi siswa. Peningkatan keterampilan bermain drama siswa dapat dilihat pada proses pembelajaran. yang ditunjukkan oleh keaktifan siswa, keberanian siswa dalam mengemukakan pendapat, semangat siswa pada saat pembelajaran, serta kemampuan siswa untuk bekerja sama dengan siswa lain.

Hasil penelitian juga menunjukkan adanya peningkatan kemampuan bermain drama siswa ke arah yang lebih baik yaitu siswa berani bermain drama dengan penuh penghayatan dan dengan gerakan-gerakan yang sesuai dengan dialog. Dari segi kebahasaan, siswa sudah mampu bermain drama dengan menggunakan intonasi yang bervariasi serta artikulasi yang jelas. Hal ini ditunjukkan dengan jumlah skor yang meningkat setelah implementasi tindakan pada tiap siklus. Nilai rata-rata bermain drama siswa pada pratindakan sebesar 49,46 siklus I sebesar 63,5, dan siklus II sebesar 78,14. Jadi skor rata-rata dari pratindakan ke siklus II meningkat sebesar 28,68. dengan lebih dari $75 \%$ siswa yang mengikuti pembelajaran telah mencapai nilai kriteria kelulusan minimal (KKM) sebesar 72.

\section{Saran}

Beberapa saran yang dapat disampaikan dengan hasil penelitian ini adalah sebagai berikut.

a) Bagi guru, teknik pembelajaran ini hendaknya digunakan secara terus menerus dan berkelanjutan, mengingat kemampuan bermain drama dapat ditingkatkan dan dipantau jika dilakukan secara berkesinambungan.

b) Bagi sekolah, pembelajaran dengan menggunakan teknik pembelajaran rotating roles perlu dikembangkan dan didukung dengan penyediaan berbagai sarana yang menunjang seperti ruang khusus untuk berlatih, sehingga kualitas siswa dan sekolah dapat terus ditingkatkan.

c) Bagi peneliti lain, dapat mengadakan penelitian mengenai peningkatan keterampilan bermain drama dengan melibatkan faktor lain sehingga dapat diketahui pengaruhnya dalam tindakan yang berbeda.

\section{Daftar Pustaka}

Sumitro, dkk. 2006. Pengantar Ilmu Pendidikan. Yogyakarta: UNY Press.

Haryadi. 1997. Peningkatan Keterampilan Berbahasa. Jakarta: Depdikbud.

Waluyo, Herman J. 2010. Drama "Teori Pembelajarannya”. Yogyakarta: PT. Hanindita Graha Widya Yogyakarta.

Harymawan, RMA. 1993. Dramaturgi. Bandung: BIT PT Remaja Rosdakarya.

Endraswara, Suwardi. 2005. Metode dan teori Pembelajaran Sastra. Yogyakarta: Buana Pustaka.

Silberman, Melvin. 2011. Aktif Learning (101 Cara belajar siswa aktif). Bandung: NUSAMEDIA

Arikunto, Suharsimi, dkk. 2006. Penelitian Tindakan Kelas. Jakarta: Bumi Persada.

Direktorat Riset dan Pengabdian Masyarakat. 2018. Jakarta : Kementerian Riset, Teknologi dan Pendidikan Tinggi. 